\title{
ALJABAR: TANTANGAN BESERTA PEMBELAJARANNYA
}

\author{
Ariyadi Wijaya \\ a.wijaya@uny.ac.id \\ Jurdik Matematika - FMIPA Universitas Negeri Yogyakarta \\ 2016
}

\begin{abstract}
Abstrak.
Kesalahan atau kesulitan belajar bisa menjadi sumber penting dalam pembelajaran. Terdapat beberapa jenis kesulitan belajar aljabar yang dialami siswa, yaitu: (a) kesalahan dalam memahami lambang '='; (2) tendensi penggunaan prosedur aritmatika dan pengabaian variabel; (3) generalisasi; (4) abstraksi; dan (5) pemaknaan grafik. Dengan mengetahui jenis kesulitan belajar tersebut maka guru bisa merancang pembelajaran yang tepat. Lebih lanjut lagi, jika merujuk pada pendidikan matematika realistik, terdapat empat pandangan tentang belajar aljabar, yaitu: (1) aljabar sebagai aktivitas manusia (algebra as human activity); (2) aljabar sebagai aktivitas otak (algebra as brain activity); (3) aljabar sebagai aktivitas personal (algebra as personal activity); dan (4) aljabar sebagai aktivitas yang bermakna (algebra as meaningful activity).
\end{abstract}

Kata kunci: kesulitan belajar aljabar, pembelajaran aljabar

\begin{abstract}
Errors or difficulties in learning could be an important source of learning. There are several types of students' difficulties in learning algebra, namely: (1) Errors in understanding the symbol '='; (2) Tendency to use arithmetic procedures and to ignore variables; (3) Generalization; (4) Abstraction; and (5) Graph interpretation. Teacher can design appropriate learning by identifying those students' difficulties. Furthermore, there are four views about learning algebra referring to Realistic Mathematics Education: 1) algebra as human activity; (2) algebra as brain activity; (3) algebra as personal activity; (4) algebra as meaningful activity.
\end{abstract}

Keywords: difficulties in learning algebra, algebra learning.

\section{Pendahuluan}

\section{Apa itu Aljabar?}

Sejauh ini tidak ada definisi pasti tentang aljabar sehingga apa yang bisa kita lakukan adalah mengidentifikasi karakteristik ataupun issue terkait aljabar. Ketika mendengar kata 'aljabar' di sekolah, hal yang terlintas bagi kita mayoritas adalah variabel, persamaan, ataupun pertidaksamaan. Lalu, apakah issue aljabar hanya terbatas pada istilah tersebut? Freudenthal (1977, pp. 193 - 194) mendeskripsikan aljabar sebagai:

\section{"It is the kind of algebra the Babylonians started with. Was their}

algebra not algebra, because their symbolism was not smooth enough? Are 'length' and 'width' much worse than ' $x$ ' and ' $y$ ' if you can give clear recipes for solving quadratic equations in such terms? Is it not algebra if the sum of the first 10 squares is laid down in a numerical formula that allows one to extend the result to any $n$ ? This ability to describe relations and solving procedures, and the techniques involved in a general way, is in my view of algebra such an important feature of algebraic thinking that I am willing to extend the name 'algebra' to it, as long as no other name is proposed, and as 
far as I know no other name has been put forward."

Secara umum, Freudenthal berpendapat bahwa aljabar tidak hanya sebatas pada simbol atau variabel. Dia memulai deskripsi tentang aljabar dengan meninjau kembali salah satu fitur aljabar yang terkenal, yaitu variabel. Freudenthal menggarisbawahi bahwa variabel lebih dari sekadar simbol dalam bentuk huruf. Akhirnya, Freudenthal mengakhiri deksripsinya dengan menekankan bahwa aljabar juga mencakup 'relasi'. Dia menekankan bahwa relasi merupakan salah satu unsur penting dari berpikir aljabar. Sejalan dengan Freudenthal, National Council of Teachers of Mathematics ([NCTM], 2000) menyatakan bahwa memahami relasi dan pola merupakan luaran penting dari belajar aljabar. Menyediakan kesempatan kepada siswa untuk bekerja dengan relasi matematis (mathematical relationships) akan memberikan kontribusi pada pengembangan kemampuan berpikir relasional (relational thinking) dan berpikir fungsional (functional thinking). Dalam Programme for International Student Assessment (PISA) (OECD, 2013), kemampuan siswa untuk berpikir secara aljabar dan menyelesaikan permasalahan aljabar termuat dalam domain 'change and relationships' atau 'perubahan dan relasi'. Hal ini menegaskan pendapat Freudenthal bahwa terdapat hubungan yang kuat antara aljabar dan relasi.

Mempertimbangkan luasnya cakupan aljabar yang lebih dari sekadar variabel seharusnya membuat kita memperluas tujuan pembelajaran aljabar. Pembelajaran aljabar sebaiknya ditujukan untuk mengembangkan kemampuan siswa dalam: (1) memahami pola, relasi, dan fungsi; (2) merepresentasikan dan menganalisis situasi matematis menggunakan symbol dan prosedur aljabar; (3) menggunakan model matematika untuk menyatakan dan memahami relasi kuantitatif; dan (4) menganalisis perubahan dalam berbagai konteks yang bervariasi (NCTM, 2010). Dalam perspektif yang lebih luas, Drijvers, Goddijn, and Kindt (2010) menggunakan istilah 'algebraic expertise' atau 'kepakaran aljabar' yang merujuk pada kemampuan siswa dalam menggunakan aljabar. Mereka berpendapat bahwa kepakaran aljabar mencakup tidak hanya penguasaan keterampilan dasar (basic skills), tetapi kepekaan symbol (symbol sense) (lihat Gambar 1). Keterampilan dasar mencakup pekerjaan prosedural (procedural work) dan menekankan pada perhitungan aljabar (algebraic calculation). Contoh keterampilan dasar aljabar adalah menyederhanakan atau menjabarkan bentuk aljabar dan melaksanakan prosedur dalam menyelesaikan persamaan. Pada sisi lain, kepekaan simbol lebih dari sekadar perhitungan. Menurut Arcavi (2005), symbol sense memegang peranan penting dalam koordinasi dan interpretasi operasi dasar aljabar. Symbol sense mencakup keterampilan strategis (strategic skill) dan kemampuan dalam penalaran aljabar (algebraic reasoning). Keterampilan strategis (strategic skill) adalah kemampuan dalam membuat dan/atau memilih strategi efektif dan mencari alternatif strategi. Kemampuan penalaran aljabar mencakup refleksi kualitatif (qualitative reflections) terhadap bentuk aljabar dan penerapannya. Lebih lanjut lagi, penalaran aljabar juga mencakup proses generalisasi pengalaman dengan bilangan dan perhitungan, formalisasi ide dengan menggunakan sistem simbol yang bermakna, dan eksplorasi konsep dari pola dan fungsi (Van de Walle, Karp, \& BayWilliams, 2013). Kaput (2008) menyebutkan ada tiga aspek penalaran aljabar, yaitu (1) studi tentang struktur sistem bilangan, seperti halnya dalam aritmatika (hal ini berkaitan dengan pandangan bahwa aljabar sebagai generalisasi dari aritmatika atau algebra as generalized arithmetic), (2) studi tentang pola, hubungan, dan fungsi, (3) proses pemodelan matematika, termasuk di dalamnya adalah penggunaan simbol secara bermakna. Ketiga aspek ini berkaitan dengan generalisasi dan simbolisasi. 


\section{Algebraic Expertise}

Basic skills:

- Procedural work

- Algebraic calculation
Symbol sense:

- Strategic work

- Algebraic reasoning

Gambar 1. Algebraic expertise sebagai suatu dimensi yang terdiri dari basic skills dan symbol sense (Drijvers, Goddijn, \& Kindt, 2010, p. 22)

Menurut Drijvers dkk (2010), algebraic expertise membutuhkan keterkaitan antara basic skills dan symbol sense. Suatu elemen tidak akan terbentuk tanpa adanya elemen yang lain; sebagai contoh adalah siswa tidak dapat bernalar secara aljabar jika mereka tidak bisa melakukan operasi aljabar dan begitu juga sebaliknya siswa seringkali membutuhkan penalaran aljabar untuk melakukan operasi aljabar. Relasi semacam itu menunjukkan bahwa guru perlu memfasilitasi siswa untuk menguasai kedua elemen tersebut. Inti dari algebraic expertise adalah bagaimana siswa bisa mengaitkan kerja prosedural (procedural work) dengan kerja strategis (strategic work) serta perhitungan aljabar (algebraic calculation) dengan penalaran aljabar (algebraic reasoning).

\section{Pemanfaatan Kesulitan Belajar Sebagai Titik Awal Pengembangan Pembelajaran Aljabar}

Aljabar merupakan konsep yang tidak mudah, baik untuk dipelajari ataupun untuk diajarkan (Drijvers dkk, 2010). Banyak siswa mengalami kesulitan dalam mempelajari aljabar sehingga mereka memiliki algebraic expertise yang rendah.

Oleh karena itu, untuk meningkatkan algebraic expertise siswa maka seorang guru terlebih dahulu perlu mengatasi kesulitan belajar siswa. Kesulitan belajar aljabar siswa dapat dijadikan sebagai titik awal untuk mengembangkan pendekatan belajar ataupun bahan ajar yang tepat. Berikut adalah beberapa jenis kesulitan yang dialami siswa dalam belajar aljabar:

1. Pemahaman konsep lambang 'sama dengan' Lambang sama dengan terlihat sederhana, tetapi banyak siswa yang salah memahami lambang tersebut. Faulkner, Levi, dan Carpenter (1999) melaporkan bahwa dari 145 siswa kelas 6 tidak ada yang bisa memberikan jawaban benar untuk soal ' $8+4=\square+5$ '. Namun, hal yang menarik adalah siswa tersebut tidak mengalami kesulitan dalam menyelesaikan soal ' $8+4=\ldots$ " ataupun ' $8 \times$ $45=\ldots$ '. Beberapa penelitian (misal: Carpenter et al., 2003; McNeil et al., 2006; Molina \& Ambrose, 2006) mengungkap bahwa siswa lebih memandang lambang 'sama dengan' ('=') sebagai 'jawabannya adalah' atau 'eksekusi' daripada sebagai lambang yang menggambarkan kesetaraan (equivalence). Pemahaman yang benar akan lambang 'sama dengan' sangat penting bagi siswa untuk memahami dan melakukan simbolisasi hubungan antar bilangan. Lebih lanjut lagi, siswa yang tidak memahami lambang 'sama dengan' ternyata cenderung mengalami kesulitan dengan bentuk aljabar (Knuth, Stephens, McNeil, \& Alibali, 2006).

2. Tendensi penggunaan prosedur aritmatika dan pengabaian variabel

Sebagai contoh adalah siswa yang baru mempelajari aljabar mengalami kesulitan saat menyelesaikan ' $7-x=3$ ' atau ' $2+y=5$ '. Mereka mungkin bingung dengan huruf ' $x$ ' dan ' $y$ '. Siswa mungkin berpikir bahwa kedua soal tersebut tidak dapat diselesaikan karena 
bilangan tidak dapat dijumlahkan dengan huruf. Hal yang menarik adalah siswa bisa menyelesaikan soal ' $7-x=3$ ' dan ' $2+y=5$ ' jika disajikan dalam bentuk ' $7-\ldots=3$ ' or ' 2 $+\square=5$ ' seperti yang sering terdapat pada buku teks. Cukup menarik kalai kita amati bagaimana siswa tidak kesulitan dengan operasi penjumlahan (ataupun pengurangan) yang memuat '...' or ' $\square$ ', namun mereka bingung ketika lambang '...' or ' $\square$ ' digantikan dengan huruf seperti ' $x$ ' atau ' $y$ '. Hal ini menunjukkan bahwa variabel dalam bentuk huruf bukan hal yang mudah bagi siswa. Untuk mengatasi kesulitan tersebut kita bisa menggunakan operasi aritmatika sebagai titik awal mempelajari aljabar. Transisi dari operasi aritmatika menuju operasi bentuk aljabar dilakukan secara lebih halus. Sebagai contoh adalah dengan mengarahkan siswa supaya memahami bahwa huruf ' $x$ ' atau ' $y$ ' memiliki posisi yang sama dengan '...' atau ' $\square$ '.

Kesulitan operasi aljabar tidak hanya dialami siswa yang baru belajar aljabar saja. Beberapa studi (Linchevski, 1995; Linchevski \& Herscovics, 1996) menunjukkan bahwa banyak siswa usia 13 tahun tidak bisa melakukan operasi penjumlahan dan pengurangan bentuk aljabar. Siswa tersebut sering mengeluarkan (detach) variabel atau simbol pada saat melakukan operasi bentuk aljabar. Siswa mengabaikan variabel dan hanya fokus pada operasi penjumlahan. Sebagai contoh adalah soal ' $(2 x+5)+(3 x+$ 1)'. Beberapa jawaban salah yang mungkin terjadi karena pengabaian variabel adalah ' $(7 x)+(4 x)=11 x$ ', '11', atau ' $5 x x+6$ '. Kesulitan semacam ini menunjukkan betapa pentingnya pemahaman tentang konsep variabel.

3. Generalisasi

Seperti disebutkan sebelumnya bahwa aljabar tidak hanya berkaitan dengan variabel, tetapi juga relasi dan pola. Relasi dan pola tidak bisa dilepaskan dari proses generalisasi. Oleh karena itu, kita perlu memposisikan generalisasi sebagai salah satu aspek kunci dalam pembelajaran aljabar. Siswa perlu mendapatkan kesempatan untuk mempelajari, menggunakan, dan mendeskripsikan pola dan generalisasi. Terlepas dari pentingnya generalisasi dalam belajar aljabar, ternyata tidak sedikit siswa kurang bisa melakukan generalisasi. Salah satu jenis kesulitan dalam generalisasi adalah apa yang disebut oleh Drijvers dkk. (2010) sebagai 'overgeneralisasi' (overgeneralization). Sebagai contoh, siswa sering salah dalam menyederhanakan ataupun menjabarkan bentuk aljabar seperti contoh berikut:

$$
\begin{gathered}
x^{2}+y^{2}=25 \text { maka } x+y=5 \\
(x+y)^{2}=x^{2}+y^{2} \\
\sqrt{x^{2}+y^{2}}=\sqrt{x^{2}}+\sqrt{y^{2}}
\end{gathered}
$$

Kita tahu bahwa penyederhanaan ataupun penjabaran tersebut tidak benar. Namun, tahukah kita kenapa siswa membuat kesalahan semacam itu? Kirschner dan Awtry (2004) melaporkan bahwa salah satu alasan kesalahan tersebut adalah karena siswa mengamati bahwa simplifikasi ataupun penjabaran tersebut berlaku untuk operasi perkalian (' $\times$ ') seperti berikut:

$$
\begin{gathered}
\sqrt{x^{2} \times y^{2}}=\sqrt{x^{2}} \times \sqrt{y^{2}}=x y \\
5\left(x^{2}+y^{2}\right)=5 x^{2}+5 y^{2}
\end{gathered}
$$

Siswa yang melakukan kesalahan tersebut mengalami kesulitan dalam mengidentifikasi generalisasi dan tidak mengetahui batasan dari suatu generalisasi. Menurut Drijvers dkk. (2010) kesalahan tersebut dapat dihindari dengan merujuk pada contoh numeric ataupun geometris. Sebagai contoh, untuk kasus $(x+y)^{2}=x^{2}+$ $y^{2}$.

Salah satu strategi yang dapat digunakan untuk mengatasi kesalahan tersebut adalah dengan menyajikan permasalahan aljabar tersebut dalam representasi geometris berupa persegi dan persegi panjang seperti terlihat pada Gambar 2. 


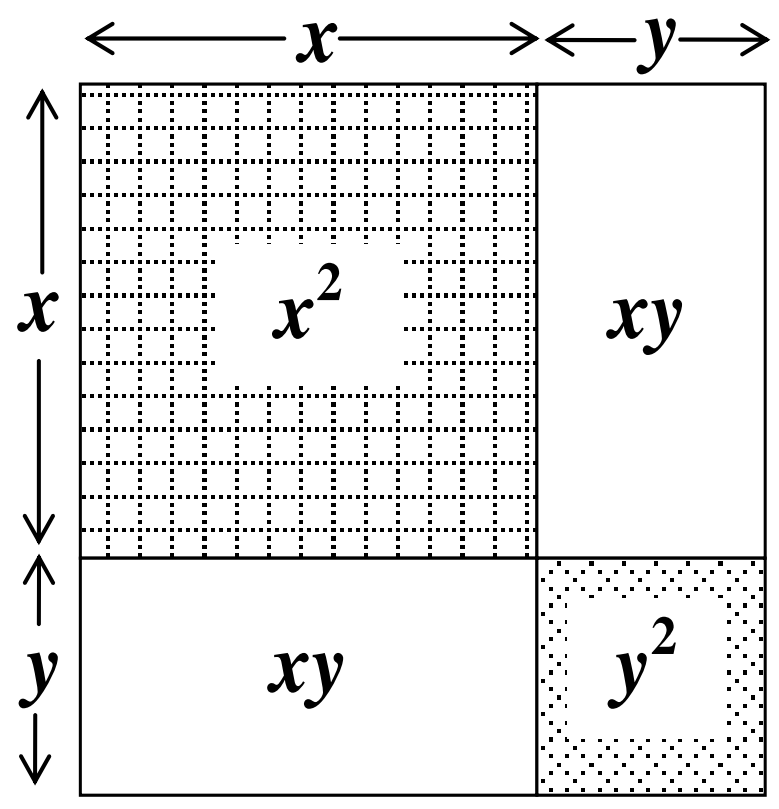

Gambar 2. Representasi geometris untuk

$$
(x+y)^{2}
$$

Dalam representasi geometris ini operasi penjumlahan ' $x+y$ ' divisualisasikan sebagai ukuran sisi suatu persegi sedangkan operasi pangkat kuadrat "...2, divisualisasikan sebagai luas persegi tersebut. Persegi besar dipartisi menjadi dua persegi kecil dan dua persegi panjang. Siswa tahu bahwa luas suatu persegi merupakan kuadrat ukuran sisinya, sehingga mereka tahu bahwa luas dua persegi kecil tersebut masing-masing $x^{2}$ dan $y^{2}$. Siswa juga sudah mengetahui bahwa luas dua persegi panjang pada gambar adalah sama, yaitu $x y$. Luas persegi besar adalah $(x+y)^{2}$.

Di sisi lain siswa diajak untuk mengamati bahwa luas persegi besar tersebut sebenarnya merupakan gabungan luas dua persegi kecil dan dua persegi panjang, yaitu, i.e. $x^{2}+y^{2}+x y+x y$. Pada akhirnya, diharapkan siswa mengetahui bahwa $(x+y)^{2}=x^{2}+2 x y+y^{2}$.

Representasi geometris cukup membantu siswa untuk operasi bentuk aljabar yang relatif sederhana seperti contoh di atas. Namun untuk soal aljabar dengan situasi yang lebih kompleks seperti terlihat pada Gambar 3 ternyata siswa masih mungkin melakukan overgeneralisasi (Drijvers dkk., 2010). Oleh karena itu, kita harus tetap merancang dan meningkatkan pembelajaran aljabar.

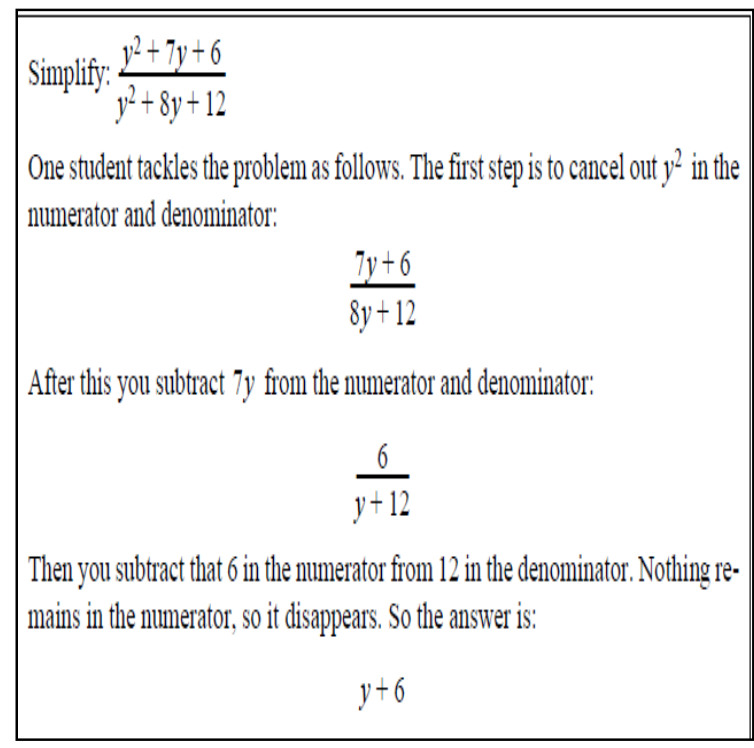

Gambar 3. Overgeneralisasi pada permasalahan kompleks (Drijvers, Goddijn, \& Kindt, 2010, p. 21)

An appliance repair company has a call outc charge of $€ 30$ and an hourly rate of $€ 45$. The following algebraic relationship applies to the cost of repair:

$$
30+\text { Repair time } \times 45=\text { Total repair cost }
$$

a. You only have $€ 100$ in cash. How long can the repair take before you exceed this amount?

b. How much does the cost go up for each hour that the repair takes?

c. Another company has a call out charge of $€ 45$ and an hoully rate of $€ 30$. Which company is the cheapest for long repairs, and which is the cheapest for short repairs? How do you decide which company to call?

Gambar 4. Soal kontekstual untuk pembelajaran aljabar (Drijvers, Goddijn, \& Kindt, 2010, p. 19)

\section{Abstraksi}

Soal kontekstual seringkali digunakan dalam pembelajaran aljabar, baik sebagai titik awal pembelajaran ataupun dalam bentuk penerapan konsep yang sudah dipelajari siswa. Contoh mudah soal kontekstual tentang aljabar yang mudah kita temui dalam buku teks adalah untuk topic sistem persamaan linear dua variabel. Gambar 4 merupakan contoh atau ilustrasi soal kontekstual untuk pembelajaran aljabar yang diberikan oleh Drijvers dkk. (2010). 
Pada contoh di atas, pertanyaan a (yaitu: Kamu hanya memiliki uang tunai sebanyak 100. Berapa lama waktu perbaikan sebelum tagihan melebihi uang yang kamu miliki?) mungkin terlihat sederhana, namun untuk beberapa siswa soal tersebut sulit. Ketika menyelesaikan suatu persamaan, siswa cenderung memulai dari sisi 'kiri' ke 'kanan'. Oleh karena itu, soal di atas akan lebih mudah bagi siswa jika mereka diminta menentukan total biaya perbaikan (total repair cost) ketika waktu perbaikan (repair time) diberikan. Namun, pada pertanyaan a di atas ternyata siswa diminta berpikir terbalik 'think backward', yaitu menentukan waktu perbaikan ketika diberikan total biaya perbaikan. Pertanyaan b lebih sulit dari pertanyaan a karena siswa perlu menginterpretasikan makna "the cost goes up for each hour" ("biaya naik setiap jam"),pertama interpretasi sesuai konteks soal, lalu secara matematis jika dikaitkan dengan rumus yang disediakan. Pertanyaan $\mathrm{c}$ menyajikan situasi baru kepada siswa dan meminta mereka untuk membuat rumus baru yang tepat. Untuk membuat rumus yang seduai dengan situasi baru tersebut, siswa dapat menyesuaikan rumus yang tersedia pada stem soal. Setelah membuat rumus baru, siswa menghadapi soal yang lebih rumit dimana mereka diminta menentukan perusahaan dengan tarif lebih murah. Soal tidak memberikan petunjuk tentang strategi yang diperlukan untuk membandingkan tarif kedua perusahaan tersebut. Pemahaman akan struktur umum situasi dan hubungan linear berperan penting saat siswa membandingkan tarif dari berbagai perusahaan.

5. Pemaknaan grafik

Aljabar tidak hanya tentang variabel dan bentuk aljabar, tetapi tidak jarang juga berkaitan dengan grafik. Banyak bentuk aljabar yang disajikan dalam bentuk grafik; sebagai contoh adalah garis lurus yang merupakan gambaran dari grafik persamaan linear. Secara umum, topik grafik mencakup dua aspek, yaitu membuat grafik (constructing graph) dan menginterpretasikan grafik (interpreting graph). Terkait kesulitan siswa dengan grafik, Leinhardt, Zaslavsky, dan Stein (1990) mengidentifikasi tiga jenis kesulitan. Kesulitan pertama adalah memperlakukan grafik sebagai gambar (treating a graph as a picture) yang menunjukkan bahwa siswa hanya fokus pada bentuk gambar secara literal dan tidak melihat sifat matematis dari grafik. Salah satu contoh kesulitan tersebut dilaporkan oleh Wijaya, Van den Heuvel-Panhuizen, Doorman, dan Robitzsch (2014) yang menemukan bahwa banyak siswa yang menganggap grafik pada soal Speed of Racing Car (Gambar 5) sebagai gambar biasa. Siswa tersebut menyatakan bahwa di antara tanda $2.6 \mathrm{~km}$ dan $2.8 \mathrm{~km}$ kecepatan mobil berkurang karena mobil sedang melewati tanjakan. Siswa memberikan jawaban tersebut karena mereka melihat grafik sebagai gambar dari kontur jalan, bukan sebagai grafik kecepatan.

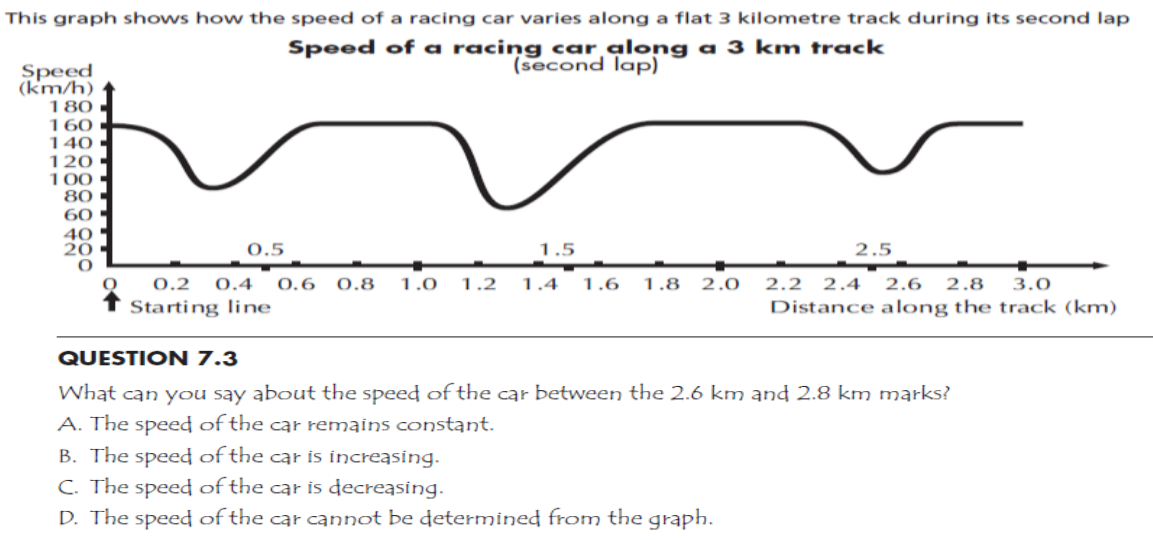

Gambar 5. Soal PISA: Speed of Racing Car problem (OECD, 2009, p. 107) 
Jenis kesalahan yang kedua adalah bingung membedakan titik dan interval (point-interval confusion). Siswa yang memiliki kesulitan ini tidak melihat bahwa suatu garis sebenarnya tersusun dari titik yang tak berhingga banyaknya. Sebagai contoh adalah siswa melihat bahwa ruas garis OA (Gambar 6) hanya memuat tiga titik, yaitu $\mathrm{O}, \mathrm{A}$, dan $\mathrm{C}$. Untuk siswa ini koordinat titik $(0.5,0.5)$ tidak terletak pada ruas garis OC. Jenis kesulitan yang terakhir adalah bingung membedakan kemiringan dan ketinggian (slope-height confusion) yang berkaitan dengan kekurangmampuan siswa dalam membedakan kemiringan garis atau gradient dengan jarak vertikal suatu titik. Siswa tersebut akan mengatakan bahwa ruas garis OA memiliki gradient yang lebih besar dibandingkan ruas garis OB. Mereka menjawab seperti itu karena ujung ruas garis $\mathrm{OB}$ lebih tinggi dibandingkan ruas garis $\mathrm{OA}$; yaitu 4 dibandingkan dengan 2 .

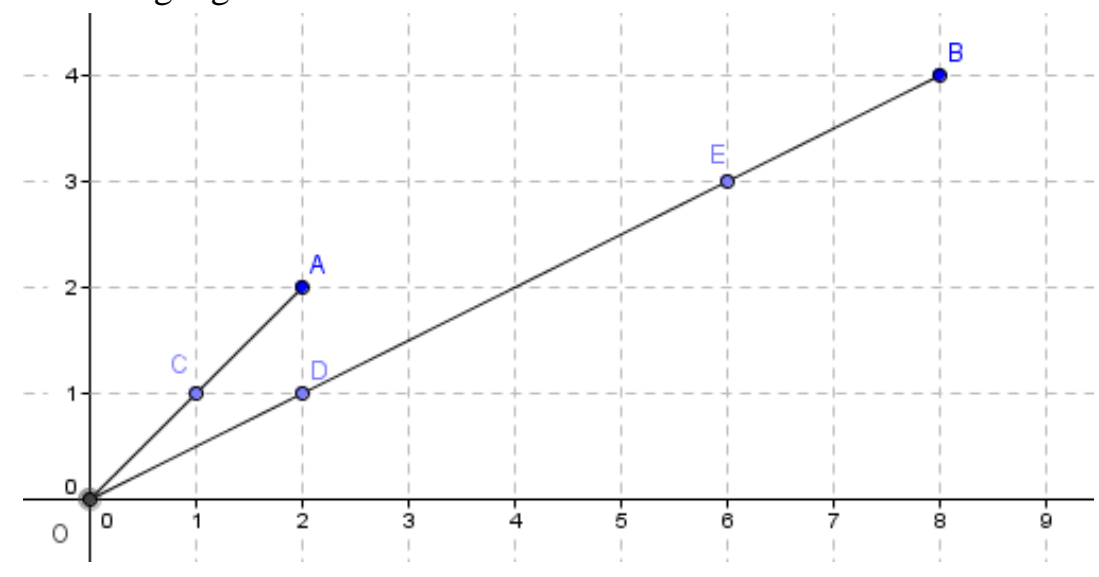

Gambar 6. Point-interval confusion dan slope-height confusion

\section{Pembelajaran Aljabar}

Drijvers dkk. (2010) menggambarkan karakteristik yang dibutuhkan untuk membuat kegiatan matematika menjadi lebih bernuansa aljabar. Menurut Drijvers dkk., aktivitas aljabar sebaiknya:

1. Memuat generalisasi, baik implicit maupun eksplisit.

2. Memfasilitasi investigasi pola dan hubungan antar bilangan dan/atau rumus.

3. Memuat soal yang dapat diselesaikan dengan menerapkan aturan umum ataupun spesifik situasional.

4. Mempromosikan penalaran logis melalui penggunaan kuantitas yang belum diketahui (unknown quantities).

5. Menggunakan variabel yang dinyatakan dalam bentuk huruf dalam operasi matematis.

6. Memuat tabel ataupun grafik untuk merepresentasikan dan/atau menyelidiki rumus atau aturan.
7. Menggunakan rumus dan ekspresi untuk memggambarkan situasi dimana unit dan kuantitas berperan penting.

Selain karakteristik di atas, secara umum terdapat empat pandangan terkait pembelajaran aljabar, yaitu aljabar sebagai aktivitas manusia (algebra as human activity), aljabar sebagai aktivitas otak (algebra as brain activity), aljabar sebagai aktivitas personal (algebra as personal activity), dan aljabar sebagai aktivitas yang bermakna (algebra as meaningful activity). Keempat pandangan ini diturunkan dari gagasan utama pendidikan matematika realistic (Drijvers dkk., 2010). Berikut penjelasan singkat terkait keempat pandangan tersebut:

\section{Algebra as human activity}

Dari sudut pandang sejarah, aljabar dikembangkan untuk memenuhi kebutuhan manusia. Oleh karena itu, kita perlu memperharikan sudut pandang sejarah tersebut dan membawa siswa untuk 
mengalami aljabar sebagai konstruksi manusia (human construction). Dengan cara ini, aljabar dipandang sebagai alat dan pengetahuan yang dapat digunakan untuk menyelesaikan permasalahan kehidupan sehari-hari.

2. Algebra as brain activity

Aljabar sebagai aktivitas otak mencakup kombinasi keterampilan dan pengetahuan. Dalam hal ini, soal kontekstual bisa berperan penting untuk menunjukkan perkembangan aljabar dari level informal menuju level abstrak.

3. Algebra as personal activity

Kegiatan personal berarti siswa sebaiknya didorong unruk merancang representasi dan mengembangkan aljabar secara independensesuai dengan alur formalisasi progresif (progressive formalization).

4. Algebra as meaningful activity

Hal penting dalam pembelajaran aljabar adalah setiap kegiatan perlu dialami (experienced) secara bermakna oleh siswa. Untuk itu, konteks yang digunakan dalam soal sebaiknya diambil dari pengalaman keseharian siswa. Pembelajaran bermakna tidak harus menggunakan permasalahan kontekstual karena permasalahan aljabar dalam bentuk abstrak juga bisa bermakna. Hal yang penting adalah siswa bisa membayangkan dan memahami apa yang mereka lakukan dengan permasalahan tersebut.

\section{Referensi}

Arcavi, A. (2005). Developing and using symbol sense in mathematics. For the Learning of Mathematics, 14(3), 42-47.

Carpenter, T.C., Franke, M.L., \& Levi, L. (2003). Thinking mathematically: integrating arithmetic and algebra in elementary school. Portsmouth, NH: Heinemann.

Drijvers, P., Goddijn, A., \& Kindt, M.. (2010). Algebra education: Exploring topics and themes. In P. Drijvers, (Ed.), Secondary Algebra Education: Revisiting topics and themes and exploring the unknown (pp. 526). Rotterdam: Sense Publishers.

Faulkner, K., Levi, L., \& Carpenter, T. C. (1999). Children's understanding of equality: a foundation for algebra. Teaching Children Mathematics, 6, 232-236.

Freudenthal, H. (1977). What is algebra and what has it been in history? Archive for history of exact sciences, 16(3), 189-200.

Kaput, J. J. (2008). What is algebra? What is algebraic reasoning? In J. J. Kaput, D. W. Carraher, \& M. L. Blanton (Eds.), Algebra in the early grades. Reston, VA: NCTM.

Kindt, M. (2004). Positive algebra. A collection of productive exercises. Utrecht: Freudenthal Institute.

Knuth, E. J., Stephens, A. C., McNeil, N. M., \& Alibali, M. W. (2006). Does understanding the equal sign matter? Evidence from solving equations. Journal for Research in Mathematics Education, 37(4), 297-312.

Leinhardt, G., Zaslavsky, O., \& Stein, M. K. (1990). Functions, graphs, and graphing: Tasks, learning, and teaching. Review of Educational Research, 60(1), 1-64.

Linchevski, L. (1995). Algebra with numbers and arithmetic with letters: a definition of prealgebra. Journal of Mathematical Behavior, 14(1), 113-120.

Linchevski, L., \& Herscovics, N. (1996). Crossing the cognitive gap between arithmetic and algebra: operating on the unknown in the context of equations. Educational Studies in Mathematics, 30(1), 39-65.

McNeil, N., Grandau, L., Knuth, E. J., Alibali, M. W., Stephens, A. C. Hattikudur, S., \& Krill, D. E. (2006). Middle-school students' misunderstanding of the equal sign: The books they read can't help. Cognition and Instruction, 24(3), 367-385.

Molina, M. \& Ambrose, R. (2006). Fostering relational thinking while negotiating the meaning of the equal sign. Teaching Children Mathematics 13(2), 111-117.

NCTM. (2000). Principles and Standard for School Mathematics. Reston: Author. 
OECD. (2003). The PISA 2003 Assessment Framework-Mathematics, Reading,

Science, and Problem Solving Knowledge and Skills. Paris: Author.

OECD. (2009). Take the test. Sample questions from OECD's PISA assessments. Paris: Author

Shell Centre for Mathematical Education. (1985). The language of functions and graphs. Shell Centre for Mathematical Education.

Van de Walle, J. A., Karp, K.S., \& Bay-Williams, J. M. (2013). Elementary and middle school mathematics. Teaching developmentally. New Jersey: Pearson.

Wijaya, A., Van den Heuvel-Panhuizen, M., Doorman, M., \& Robitzsch, A. (2014). Difficulties in solving context-based PISA mathematics tasks: An analysis of students' errors. The Mathematics Enthusiast, 11(3), $555-584$. 
JURNAL GANTANG Pendidikan Matematika FKIP - UMRAH

Vol. 1 No. 1, Agustus 2016, p-ISSN. 2503-0671, e-ISSN. 2548-5547

\section{LAMPIRAN}

\section{Contoh Aktivitas Pembelajaran Aljabar Untuk Siswa Smp}

\section{Aktivitas 1: Bekerja Dengan Variabel}

Aktivitas 1 ditujukan untuk memfasilitasi siswa untuk:

memahami makna dan konsep variabel

memahami makna dan konsep lambang "=”

\section{Mesin Bilangan}

Di suatu kota modern terdapat mesin yang disebut Mesin Bilangan. Ketika kita memasukkan suatu bilangan pada mesin maka mesin tersebut akan memproduksi bilangan lain sebagai luarannya. Sebagai contoh, mesin bilangan di bawah akan mengurangi sebarang bilangan yang dimasukkan ke mesin dengan 7.

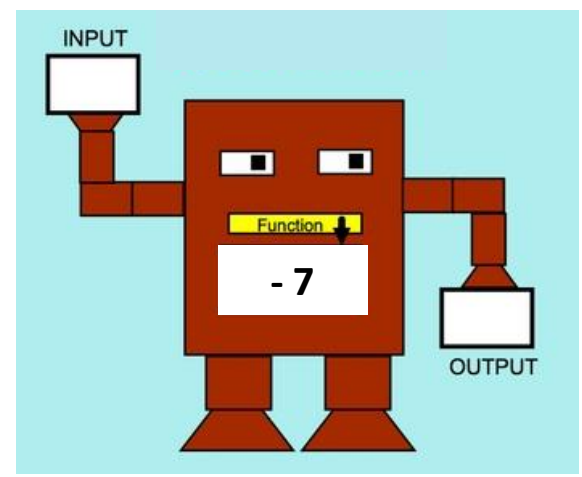

a. Lengkapi tabel berikut berdasar Mesin Bilangan di atas

\begin{tabular}{|c|c|}
\hline INPUT & OUTPUT \\
\hline 12 & \\
\hline 10 & \\
\hline 5 & \\
\hline 0 & \\
\hline-4 & \\
\hline$a$ & \\
\hline $2 a$ & \\
\hline$a-1$ & \\
\hline
\end{tabular}

b. Dapatkah sembarang bilangan bulat dijadikan sebagai input mesin? Jelaskan.

c. Dapatkah sembarang bilangan bulat menjadi output mesin? Jelaskan.

d. Adakah bilangan yang tidak mungkin menjadi output mesin tersebut?

\section{Aktivitas 2: Mengamati Pola}

Sesuai pendapat Freudenthal, aljabar tidak hanya tentang variabel tetapi juga berkaitan dengan pola.

Oleh karena itu, aktivitas 2 ini ditujukan untuk:

- $\quad$ memfasilitasi siswa untuk menyelidiki hubungan antar komponen pada suatu pola

- $\quad$ memfasilitasi peserta untuk melakukan generalisasi suatu pola 


\section{ASEAN Airshow 2016}

Formasi skuadron pesawat biasanya berupa formasi $\mathrm{V}$ yang merupakan imitasi penerbangan burung yang bermigrasi. Hal ini ditujukan untuk menghemat penggunaan bahan bakar. Saat ini formasi pesawat lebih bervariasi, salah satunya adalah formasi W seperti pada gambar berikut.

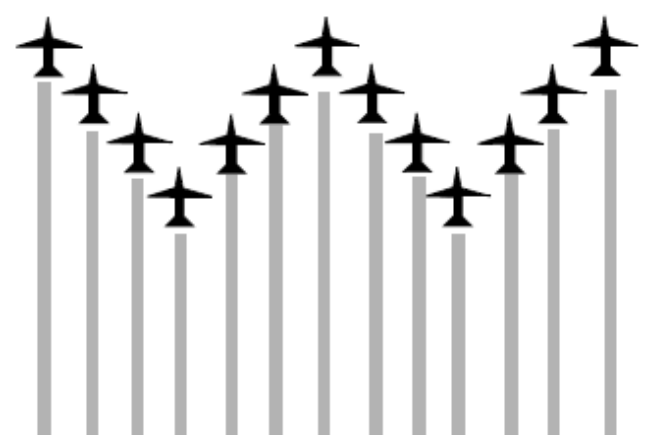

Pola di bawah merupakan kelompok titik yang membentuk formasi W.

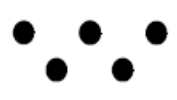

1

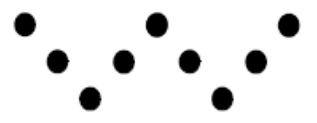

2

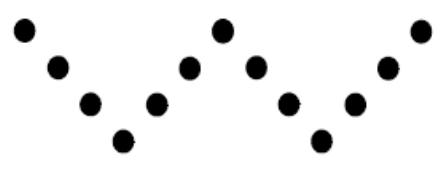

3

a. Ada berapa banyak titik pada grup yang ke-11?

b. Grup manakah yang memiliki titiks ebanyak 37 ?

c. Mungkinkah ada grup dalam formasi W tersebut yang terdiri dari 1.204 titik? Jelaskan.

d. Ada berapa banyak titik pada grup yang ke-n? Jelaskan bagaimana Anda memperoleh jawaban.

\section{Spiral Bilangan}

Martin Kindt (2004) menyusun bilangan bulat positif dalam bentuk spiral seperti terlihat pada gambar berikut.

Lengkapi spiral bilangan berikut dengan rumus atau aturan yang tepat. Jelaskan darimana Anda memperoleh rumus tersebut. 


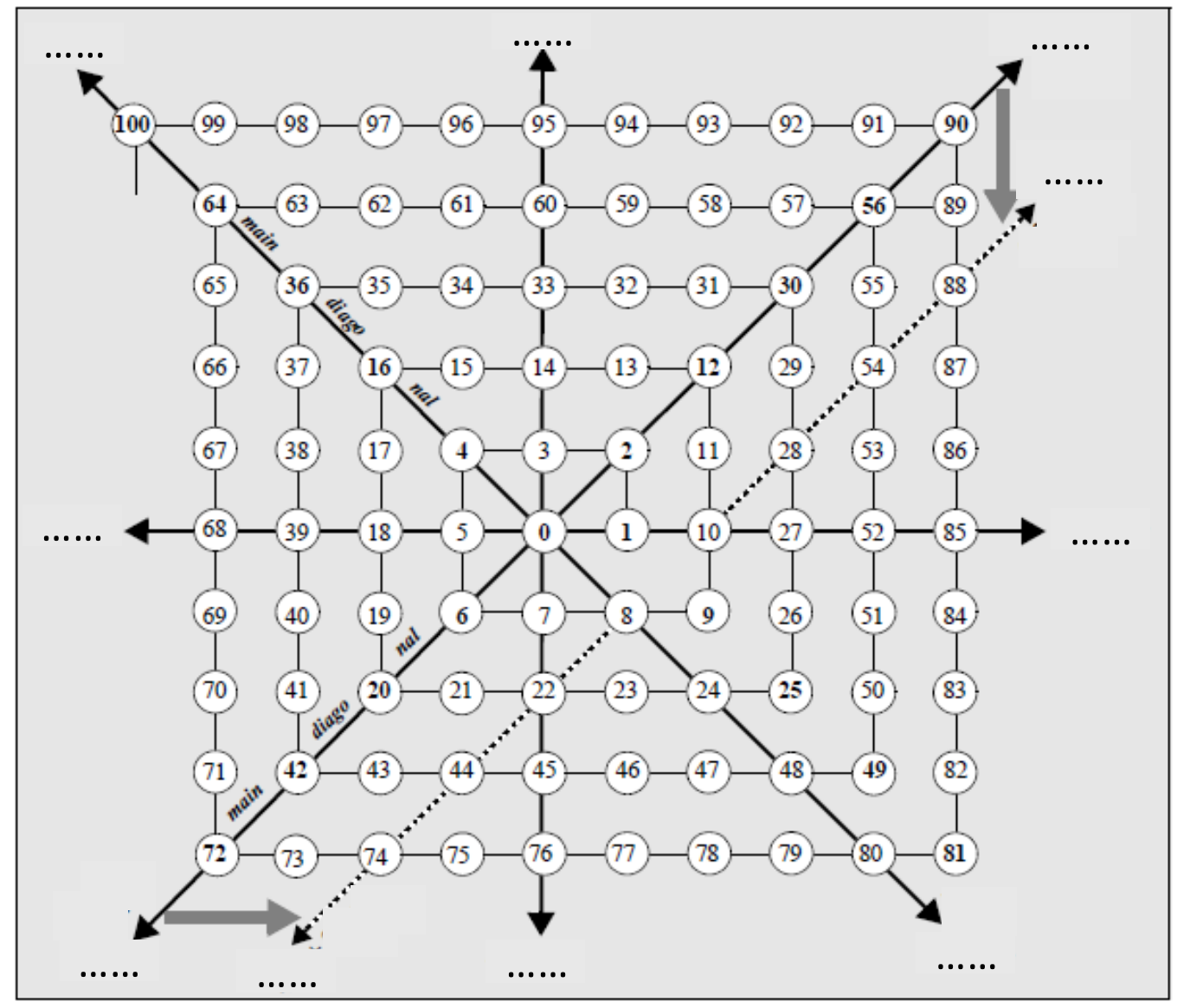




\section{Aktivitas 3:}

Pekan kemarin Bommel mengendarai mobilnya menuju pantai. Dalam perjalanan, Bommel terjebak kemacetan di tengah kota. Begitu terbebas dari kemacetan, Bommel memacu mobilnya dengan kencang. Bommel tidak menyadari bahwa dia memasuki daerah dengan kecepatan tertinggi $50 \mathrm{~km} / \mathrm{jam}$. Seorang polisi pun mengejar dan memberhentikan Bommel.

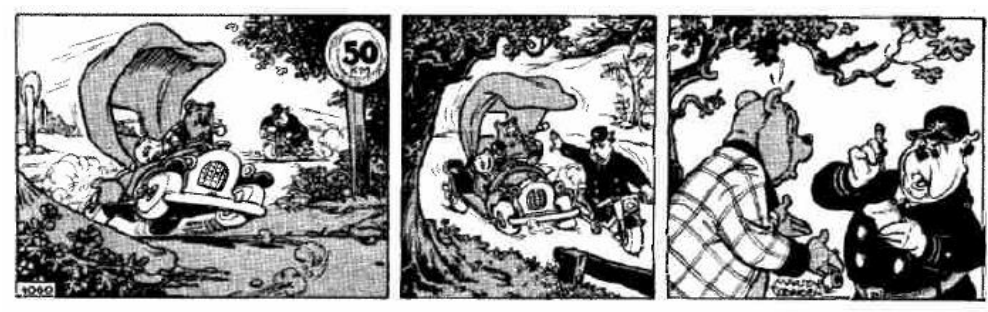

Polisi : Selamat pagi, Pak. Apakah Anda tergesa-gesa? Tidakkah Anda melihat rambu batas kecepatan di sana? Anda telah melanggar batas kecepatan tersebut.

Bommel : Selamat pagi, Pak. Maaf, saya tidak bersalah karena saya tidak mengendarai mobil dengan kencang. Dalam seperempat jam terakhir saya hanya menempuh jarak $40 \mathrm{~km}$. Dengan kata lain, kecepatan saya hanya $40 \mathrm{~km} / \mathrm{jam}$.

a. Siapakah yang benar antara polisi atau Bommel?

Misalkan grafik berikut merupakan gambaran perjalanan Bommel.

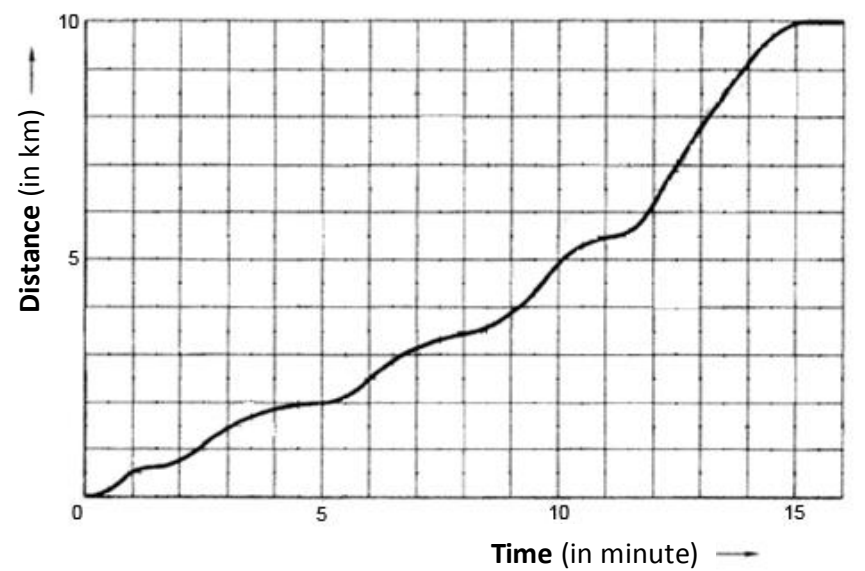

a. Berdasarkan grafik, apakah Bommel melanggar batas kecepatan? Jelaskan alasan Anda.

b. Andai Bommel melanggar batas kecepatan:

- Berapa kecepatan tertinggi yang ditempuh Bommel?

- Dalam jarak berapa kilometer Bommel melanggar batas kecepatan?

\section{Botol dan air}

Di bawah terdapat gambar enam botol berbeda dan sembilan grafik yang merepresentasikan hubungan antara volume air dan ketinggian air dalam botol. Pasangkan setiap gambar botol dengan grafik yang tepat. Jelaskan alasan Anda. 
JURNAL GANTANG Pendidikan Matematika FKIP - UMRAH

Vol. 1 No. 1, Agustus 2016, p-ISSN. 2503-0671, e-ISSN. 2548-5547
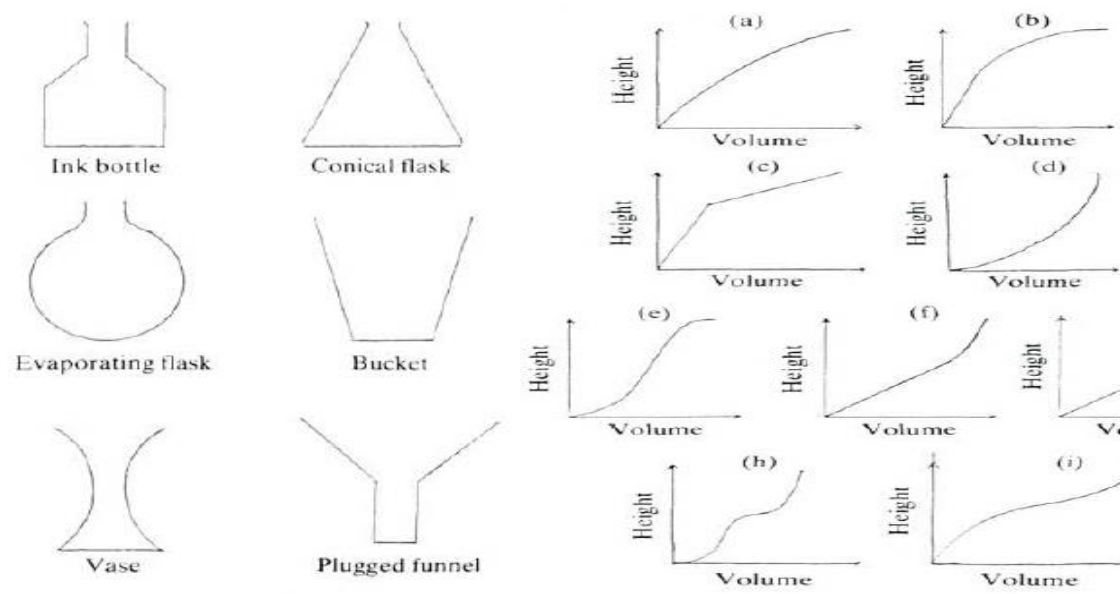

(f) $+(\mathrm{g})$
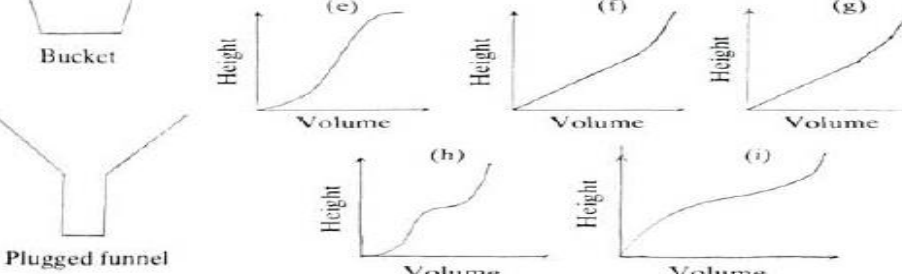

Plugged funnel

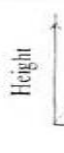

(i)

\begin{tabular}{|c|c|}
\hline Botol & Graph \\
\hline Ink bottle & \\
\hline Conical flask & \\
\hline Evaporating flask & \\
\hline Bucket & \\
\hline Vase & \\
\hline Plugged funnel & \\
\hline
\end{tabular}

